\title{
PENGARUH TEORI RECEPTIE DALAM PERKEMBANGAN HUKUM ISLAM DI INDONESIA
}

\author{
Mohamad Rana \\ Fakultas Syariah dan Ekonomi Islam \\ Institut Agama Islam Negeri Syekh Nurjati Cirebon \\ Jl. Perjuangan By Pass Sunyaragi Cirebon \\ Email: mohamadrana85@yahoo.com
}

\begin{abstract}
Abstrak
Islam sebagai agama memiliki aturan-aturan yang harus dilaksanakan oleh umatnya yang selanjutnya disebut sebagai hukum Islam. Keberadaan hukum Islam di Indonesia telah dilaksanakan seiring masuknya agama Islam itu tersendiri. Bahkan sebelum pihak kolonial Belanda datang menjajah wilayah Nusantara, hukum Islam telah dilaksanakan secara menyeluruh (kāffah) dalam berbagai aspeknya dan telah menjadi sumber hukum bagi kerajaan-kerajaan Islam di Nusantara. Datangnya Belanda ke wilayah Nusantara dengan menerapkan politik hukumnya yaitu teori receptie. Teori receptie yang merupakan gagasan dari Snouck Hurgonje memberikan implikasi besar terhadap hukum Islam yang selama ini telah diamalkan oleh umat Islam, dan pengaruhnya masih dapat dirasakan pasca kemerdekaan Indonesia.
\end{abstract}

Kata Kunci: Hukum Islam, Politik Hukum, dan Teori Receptie

\begin{abstract}
Islam as a religion has rules that must be implemented by its people, hereinafter referred to as Islamic law. The existence of Islamic law in Indonesia has been implemented as the entry of Islam is separate. Even before the Dutch colonial colonists came to occupy the archipelago, Islamic law has been implemented thoroughly (käffah) in various aspects and has become a source of law for the Islamic kingdoms in the archipelago. The arrival of the Netherlands into the archipelago by applying its legal policy of receptie theory. Receptie theory which is the idea of Snouck Hurgonje has major implications for Islamic law which has been practiced by Muslims, and its influence can still be felt after Indonesian independence.
\end{abstract}

Keywords: Islamic Law, Political Law, and Receptie Theory 


\section{PENDAHULUAN}

Hukum Islam bagi umat Islam merupakan seperangkat peraturan-peraturan yang ditetapkan Tuhan kepada manusia yang masih bersifat umum, baik berkaitan dengan masalah ibadah maupun muamalah yang dipahami dari kandungan al-Qur'an maupun Sunnah Nabi, Saw., sebagai pedoman hidup masyarakat. Syari' at Islam diyakini apabila dilaksanakan, maka akan membawa kebahagiaan hidup baik di dunia maupun diakhirat ${ }^{1}$.

Terhitung sudah 14 (empat belas) abad sejak pertama kali diwahyukan kepada Nabi Muhammad, Saw., hukum Islam mengalami dinamika dan perkembangan. Hal ini terjadi karena hukum Islam bertujuan mengatur kepentingan manusia dalam menggapai kemaslahatan dalam hidupnya. Ia senantiasa berkembang dan berjalan sesuai dengan situasi, kondisi, dan gerak laju perkembangan umat Islam. Dinamika perkembangan tersebut adakalanya mengalami kemajuan, tetapi pada waktu tertentu hukum Islam mengalami stagnasi, dan dekaden. Tak terkecuali perkembangan hukum Islam di Indonesia, pun dalam sejarahnya mengalami dinamika pasang surut, baik disebabkan karena adanya faktor eksternal, maupun faktor internal.

Dalam catatan sejarah perkembangan hukum di Indonesia, pasca masuknya Islam ke bumi nusantara hukum yang telah mapan dan melembaga dalam kehidupan masyarakat adalah hukum Islam. Hal ini dibuktikan dalam catatan sejarah, bahwa hukum Islam telah berlaku di bumi Nusantara, jauh sebelum kolonial Belanda datang, dengan dibawah kewenangan para sultan.

\footnotetext{
${ }^{1}$ Mahmud Syaltut, $A l$-Islām 'Aqīdatu wa Syarī'atu, (Beirut: Dār Syuruq, 1983), 58
}

Hukum Islam di Indonesia, dalam formulasi yang sangat sederhana dapat dinyatakan bahwa pada hakikatnya hukum Islam di Indonesia adalah norma-norma hukum yang bersumber dari syariat Islam yang tumbuh dan berkembang dalam kehidupan masyarakat sepanjang bentangan sejarah Indonesia. Ia terlahir dari hasil perkawinan normatif (syari'ah) dengan muatan-muatan lokal Indonesia secara utuh $^{2}$.

Hukum Islam yang sebelumnya telah berlaku di Nusantara, mulai berubah dengan kedatangan VOC (Vareenigde Oost Indische Compagnie) pada tahun 1595. Terlebih Pada abad ke-19 terjadi gerakan dikalangan banyak orang Belanda yang berusaha menghilangkan pengaruh hukum Islam, dengan jalan antara lain adanya kristenisasi. Karena andaikan berhasil menarik banyak penduduk pribumi untuk masuk agama Kristen, akan sangat menguntungkan kedudukan pemerintah Kolonial Belanda. Dengan asumsi bahwa yang telah menganut agama Kristen akan menjadi warga negara yang loyal dan patuh kepada pemerintah Kolonial Belanda ${ }^{3}$. Hal ini diperparah lagi dengan munculnya teori receptie yang dikemukakan oleh Christian Snouck Hurgronje Hurgranje (1857-1936). Realitas tersebut membuat posisi hukum Islam yang sebelumnya memiliki tempat tersendiri dikalangan umat Islam, oleh pihak kolonial Belanda diupayakan untuk dihilangkan.

Diakui ataupun tidak, keberadaan teori receptie pada akhirnya mempengaruhi perkembangan hukum Islam itu sendiri, pada periode-periode selanjutnya pasca kemerdekaan Republik Indonesia.

2 Lihat, Abd. Halim Barakatullah dan Teguh Prasetyo, Hukum Islam Menjawab Tantangan Zaman Yang Terus Berkembang, cet. 1, (Yogyakarta: Pustaka Pelajar, 2006), 68.

${ }^{3}$ Deliar Noer, Gerakan Modern Islam di Indonesia 1900-1942 (Jakarta: LP3ES, 1985), 183 


\section{HUKUM ISLAM PRA KOLONIAL BELANDA}

Awal masuknya Islam sempat menjadi perbincangan hangat dikalangan para pegiat dan pemerhati sejarah dari berbagai kalangan. Sebagaimana yang dikatakan Nyong Eka Teguh Iman Santosa $^{4}$, bahwa lokus diskusi mengenai kedatangan Islam di Indonesia sejauh ini berkisar pada tiga tema utama, yakni: tempat asal kedatangannya, para pembawanya, dan waktu kedatangannya. Hal lain yang patut diperhatikan adalah dimensi proses dari interaksi awal dan lanjutan antara Islam dan penduduk lokal berikut konstruk kepercayaan atau agama yang telah ada sebelumnya.

Mengenai tempat asal kedatangan Islam ke Indonesia ada beberapa teori besar yang berkembang dikalangan sejarawan, menurut Azyumardi Azra menyatakan ada tiga asal masuknya Islam ke Indonesia yaitu Mekah, Gujarat, dan Benggal. Berbeda dengan A.M. Suryanegara yang juga mengemukakan tiga teori yaitu dari Mekah, Gujarat dan Persia. Berikut ini penulis uraikan teori-teori yang berkembang berkenaan tempat asal Islam yang ada di Indonesia berdasarkan teori yang dipegang oleh Azyumardi Azra5:

Kesatu, teori Gujarat. Teori ini berkembang berdasarkan atas pandangan yang mengatakan asal daerah yang membawa Islam ke Nusantara adalah dari Gujarat. Peletak dasar teori ini pertama

\footnotetext{
4 Nyong Eka Teguh Iman Santosa, dalam "Membaca Masuknya Islam di Indonesia", eprints.umsida.ac.id/184/.../teori\%20masuknya\%20I slam\%20ke\%20nusantara-2005, diakses 15 Januari 2018.

${ }^{5}$ Lihat, Abdul Ghofur, dalam "Tela'ah K ritis M asuk dan Berkembangnya Islam di Nusantara, http://ejournal.uinsuska.ac.id/index.php/ushuludin/article/view/689. Diakses 12 Januari 2018
}

dikemukakan oleh Pijnepel (1872 M) yang menafsirkan catatan perjalanan Sulaiman, Marcopolo dan Ibn Batutah. Teori ini dikemudian hari mendapat dukungan dari Snouck Hurgronje Hurgranje yang mendasarkan dengan alasan-alasan berikut ini:

1) Kurangnya fakta yang menjelaskan peranan bangsa Arab dalam penyebaran agama Islam ke Nusantara;

2) Hubungan dagang antara IndonesiaIndia telah lama terjalin dengan baik;

3) Inskripsi tertua tentang Islam yang terdapat di Sumatera memberikan gambaran hubungan dagang antara Sumatera dan Gujarat.

Pandangan Snouck Hurgronje Hurgranje tersebut memiliki pengaruh besar pada masa-masa selanjutnya karena mendapat legitimasi dari sejarawan Barat antara lain Stutterheim dalam karyanya (De Islam en Zijn Komst in De Archple), Bernard H.N. Vlekke (Nusantara History of Indonesia), Schriekie (Indonesian Sociological Studies), Clifford Geertz (The Religion of Java), Harry J.Benda (A History of Modern South East Asia) Van Leur (Indonesian Trade and society), T.W. Arnold (The Preaching of Islam).

Moquette, seorang sarjana Belanda lainnya berkesimpulan bahwa tempat asal Islam di Nusantara adalah Gujarat. Kesimpulannya muncul setelah ia mengamati bentuk batu nisan di Pasai, kawasan Utara Sumatra (Aceh sekarang) khususnya yang bertanggal 17 Dzulhijjah 831H/ 27 September 1428 M. Batu Nisan yang dilihatnya memiliki kemiripan dengan batu nisan lain yang ditemukan di makam Maulana Malik Ibrahim (w. 822/1419M) di Gresik Jawa Timur ternyata memiliki kesamaan bentuk dengan batu nisan yang 
terdapat di Cambay Gujarat. Berdasarkan contoh-contoh batu nisan inilah ia berkesimpulan bahwa batu nisan dari Gujarat bukan hanya untuk pasar lokal, tetapi juga diimpor ke kawasan lain. Salah satunya ke wilayah Nusantara.

Kedua, Teori Mekkah. Teori ini lebih belakangan lahirnya jika dibandingkan dengan teori Gujarat yang telah lama muncul dalam khazanah ilmu pengetahuan sejarah. Teori Mekah baru muncul sekitar tahun 1958 M, sementara Teori Gujarat telah sejak tahun $1872 \mathrm{M}$. Teori Mekah muncul ketika banyaknya kritikan yang ditujukan pada teori Gujarat karena terdapat sisi-sisi lain yang tidak terungkap sehingga melemahkan teori itu sendiri.

Ketiga, Teori Benggali (Bangladesh). Teori ini lahir berdasarkan realitas di Pasai, mayoritas orang terkemuka didaerah tersebut adalah orang Benggali atau keturunan mereka. Islam yang muncul pertama kali di Semenanjung Malaya adalah dari arah pantai Timur, bukan dari Barat (Malaka), yaitu melalui Kanton, Phanrang (Vietnam), Leran, dan Trengganu. Jika merujuk pada doktrin ajaran (madzhab), Islam di Semenanjung sama dengan Islam di Phanrang, sementara elemen prasasti yang ditemukan di Trengganu juga mirip dengan prasasti yang ditemukan Leran. Teori yang dikembangkan oleh Fatimi ini dikritik oleh Drewes. Dia mengatakan bahwa bukti-bukti yang ada, terutama terkait dengan prasasti ini merupakan "perkiraan liar". Teori ini semakin lemah dengan adanya kenyataan bahwa madzhab hukum yang dominan di Benggali adalah Hanafi, bukan Syafi' ${ }^{6}$.

Terlepas teori-teori di atas terkait darimana asal Islam yang berkembang di Indonesia, satu hal yang pasti bahwa potret sejarah legislasi hukum Islam di Indonesia sebenarnya dapat dibaca mulai masuknya Islam ke negeri ini, yaitu pada abad pertama Hijrah (abad ke 7 atau $8 \mathrm{M})^{7}$. Sehingga

${ }^{6}$ Lihat, Abdul Ghofur, Tela'ah Kritis Masuk... 161163, juga lihat, Mahsun Fuad, Hukum Islam Indonesia, (Yogjakarta: LKIS, 2005), 27-30

${ }^{7}$ Secara umum ada dua pendapat mengenai kapan masuknya Islam ke Nusantara: pertama, bahwa Islam masuk ke Indonesia pada abad pertama Hijrah (abad ke 7 atau $8 \mathrm{M}$ ). Pendapat ini dianut oleh sebagian besar sejarawan muslim Indonesia dan Malaysia antara lain S.Q. Fattimi; A. Hasyimi; Hamka; Sayyid Mohammad Naquib Al-Attas dan sejarawan yang ikut hadir dan mendukung diseminar "Islam Masuk dan Berkembang di Nusantara" baik ketika dilaksanakan di Medan maupun di Aceh. Dan juga mendapat dukungan dari beberapa sejarawan dari Barat yaitu Van Leur dan T.W. Arnold. Argumentasi yang dikemukakan oleh pendapat yang pertama adalah sejak abad ke $4 \mathrm{M}$ telah ada jalur transportasi yang menghubungkan Teluk Parsi, India, dan daratan Cina. Di daratan Cina ini ada catatan tentang kedatangan orang Islam pertama pada awal pemerintahan Dinasti Tang (618-07 M), yaitu orang Persia (615 M); utusan yang datang kedua adalah terjadi pada tahun $655 \mathrm{M}$ kemudian terdapat pula utusann ketiga orang Persia pada tahun 681M. Pada masa pemerintahan Bani Umayyah dikirim 17 utusan diplomatic kepada pemerintahan Cina yaitu antara tahun 661-751 M. Dari hubungan ini terbentuklah beberapa pemukiman masyarakat muslim di pesisir pantai di Cina dan waktu itu sudah ada orang Cina yang memeluk Islam. Argumen selanjutnnya adalah berdasarkan kesimpulan dari seminar masuk dann berkembangnya Islam di Nusantara, baik yang diselenggarakan tahun 1963M di Medan sekala nasional; di Aceh tahun 1978M sekala Nasional dan tahun 1980 M di Aceh Timur sekala Internasional. Kedua, Islam masuk ke wilayah Nusantara menurut pendapat kelompok kedua ini adalah terjadi pada abad ke $13 \mathrm{M}$. Pendapat ini didukung oleh sebagian besar sejarawan Barat khususnya yang berasal dari Belanda antara lain Brian Barrison; D.G.E Hall; P.M. Holt; W.F. Stuterhein; Snough Hurgronye dan lainnya. Pendapat ini didasarkan atas sumbersumber asing yang ditulis oleh orang-orang Eropa seperti W.F. Stuterhein; di mana ia berpendapat bahwa Islam masuk ke Nusantara pada abad ke 13 M dengan dasar atas bukti Batu Nisan Sultan 
secara sosiologis dan kultural, hukum Islam telah menyatu dan menjadi hukum yang hidup (living law) di dalam masyarakat. Bukan saja karena hukum Islam merupakan entitas agama yang dianut oleh mayoritas penduduk hingga saat ini, akan tetapi dalam dimensi amaliahnya di beberapa daerah ia telah menjadi bagian tradisi (adat) masyarakat, yang terkadang dianggap sakral $^{8}$.

Hal ini terjadi karena telah terjadi proses akulturasi antara hukum Islam dengan budaya lokal, atau dengan pengertian lain, telah terjadi pembauran antara tradisi besar (fikih Islam) dengan tradisi kecil (adat), yaitu suatu pengakuan dan legitimasi Islam ke dalam tradisi masyarakat ${ }^{9}$. Dalam pandangan Cik Hasan Bisri, hal tersebut digambarkan dengan istilah integrasi antara hukum Islam dengan kaidah lokal ke dalam pranata-pranata sosial $^{10}$.

Pembauran hukum Islam dengan adat lokal pada gilirannya menjadi sesuatu yang

pertama di kerajaan Samudra Pasai yaitu Sultan AlMalik Al-Saleh yang wafat 1292 M. Singgahnya Marcopolo selama 5 bulan di pesisir panntai Utara Sumatra (Aceh sekarang) tahun 1292 M, lalu ia menjelaskan bahwa seluruh penduduk setempat masih menganut kepercayaan Pelbagu, kecuali di suatu kerajaan yaitu Peurlak yang terletak di ujung Timur laut pulau Sumatra telah memeluk Islam, dan itupun hanya penduduk kota (pesisir pantai) yang memeluk Islam. Lihat, Taufik Abdullah, Sejarah Dan Masyarakat : Lintasan Historis Islam di Indonesia, (Jakarta: Yayasan Obor Indonesia, 1994), 1. Lihat juga, Abdul Aziz Thabba, Islam dan Negara Dalam Politik Orde Baru, (Jakarta : Gema Insani Press, 1998), 115. Juga, Ahmad.Mansur Surya Negara, Menemukan Sejarah: Wacana Pergerakan Islam di Indonesia, (Bandung: Mizan, 2002), 76. Juga lihat, Abd. Ghofur, Tela'ah Kritis Masuk dan Berkembangnya Islam.. 166-167

8 Marzuki Wahid dan Rumadi, Fiqh Madzhab Negara, (Yogyakarta: LKiS, 2001), 80

9 Oyo Sunaryo Mukhlas, Perkembangan Peradilan Islam, (Bogor: Ghalia Indonesia, 2011), 119-120

10 Cik Hasan Bisri, Peradilan Agama di Indonesia, (Jakarta: Raja Grafindo Persada, 2000), 105 dipegang teguh dan dilaksanakan dengan penuh kesadaran oleh umat Islam, tidak hanya menyangkut masalah ibadah, namun dalam masalah sosial kemasyarakatan. Hal ini dapat dicermati dalam ungkapanungkapan yang mempola pada masyarakat di beberapa wiayah, seperti di Minangkabau: "adat bersendi syarak, syarak bersendi kitabullah; syarak mengata, adat memakai". Begitu pula di Aceh dikenal ungkapan: 'adat bak poteu meureuho, hukom bak syiah kuala" [Adat dari sultan, hukum dari ulama].

Walaupun secara yuridis, norma dan regulasi yang mengikat untuk melaksanakan hukum Islam, terutama dalam menyelesaikan perkara itu belum ada. Namun, secara de facto, praktik menyelesaikan perkara dan menerapkan berlakunya hukum Islam secara kāffah sudah banyak dirasakan langsung oleh masyarakat Islam $^{11}$. Ketiadaan regulasi maupun norma disebabkan, karena pada masa-masa ini belum adanya kekuasaan/pemerintahan yang mengakomodir Islam sebagai agama resmi dan sumber hukum. Sehingga, persoalanpersoalan yang muncul di kalangan masyarakat Islam diselesaikan sepenuhnya oleh lembaga tahkīm.

Seiring dengan berdirinya kerajaankerajaan Islam, wewenang kekuasaan yang selama ini dipegang oleh lembaga tahkīm dipindahkan dan diberikan kepada pengadilan. Hal ini dimaksudkan agar hukum Islam benar-benar dapat ditegakkan dan sekaligus merupakan penjabaran lebih lanjut dari aktivitas keulamaan dalam memberikan layanan keagamaan kepada masyarakat. Dari situ muncullah berbagai lembaga pengadilan Islam di beberapa tempat, di antaranya: Pengadilan Surambi di Jawa, Mahkamah Syar'iyyah di

\footnotetext{
11 Oyo Sunaryo Mukhlas, Perkembangan Peradilan... 120
} 
Sumatera, dan Kerapatan Qadi di Banjar dan Pontianak. Lembaga-lembaga pengadilan ini tidak hanya menuntaskan persoalan perdata semata, namun juga menangani persoalan pidana ${ }^{12}$.

Bisa dikatakan bahwa Islam dan masyarakat Nusantara ketika itu ibarat dua sisi mata uang yang tidak terpisahkan. Terjadinya konversi secara besar-besaran masyarakat Nusantara kepada Islam $^{13}$ memberi kedudukan penting bagi Islam dalam sosial politik. Hukum Islam pun secara otomatis berlaku dalam kerajaankerajaan Islam yang ada pada waktu itu.

Fenomena hukum Islam sebagai hukum yang hidup di masyarakat, dengan raja (sultan) sebagai pemegang kekuasaan tertinggi, telah melahirkan satu teori kredo atau syahadat dikalangan pemerhati hukum Islam. Teori yang sesungguhnya merupakan kelanjutan dari prinsip tauhid dalam filsafat hukum Islam ini mengharuskan pelaksanaan hukum Islam bagi mereka yang telah mengucapkan dua kalimat syahadat $^{14}$.

Penerapan hukum Islam di bumi Nusantara pada kalangan masyarakat Islam pun diakui kalangan ahli hukum dan

12 Lihat, Mahsun Fuad, Hukum Islam Indonesia, (Jokjakarta: LKIS, 2005), 49. Juga lihat, Bustanul Arifin, Pelembagaan Hukum Islam diIndonesia: Akar Sejarah dan Prospeknya, (Jakarta: Gema Insani Press, 1996), 78

${ }^{13}$ Fachry Ali dan Bahtiar Effendy mengungkapkan tiga faktor utama yang mempercepat proses islamisasi di Nusantara. Pertama, prinsip tauhid dalam Islam yang mengimplikasikan pebebasan manusia dari kekuatan-kekuatan selain Allah; Kedua, daya lentur ajaran Islam yang dapat mengakomodasi nilai-nilai lokal yang tidak bertentangan dengan ajaran-ajaran Islam; dan Ketiga, sifat Islam yang anti penjajahan kelak menjadi kekuatan politik tersendiri dalam menghadapi ekspansi bangsa-bangsa Barat di Nusantara. Lihat, Fachry Ali dan Bahtiar Effendy, Merambah Jalan Baru Islam Rekonstruksi Pemikiran Islam Indonesia Masa Orde Baru, (Bandung: Mizan, 1986), 32-34.

${ }^{14}$ Mahsun Fuad, Hukum Islam... 50 kebudayaan Belanda, bahwa sejak tahun 1800 M, Islam merupakan agama yang sangat dijunjung tinggi oleh pemelukpemeluknya, dan setiap masalah kemasyarakatan yang muncul senantiasa merujuk kepada ajaran hukum Islam, baik permasalahan ibadah, politik, ekonomi, dan masalah-masalah lain, termasuk dalam bidang peradilan ${ }^{15}$.

Melihat realitas tersebut, hal pertama yang dilakukan oleh pihak kolonial Belanda pada awal kedatangannya di bumi Nusantara adalah dengan membiarkan pemberlakuan hukum Islam bagi pemeluknya secara keseluruhan. Hal tersebut dilakukan atas saran dari Salomon Kaeyzer (1832-1927) dan LCW Van Den Berg (1845-1927), dimana mereka menyatakan bahwa hukum mengikuti agama yang dianut seseorang, yang oleh Van Den Berg disebut dengan "receptio in complexu" ${ }^{16}$. Dengan demikian, bagi orang Islam berlaku penuh hukum Islam.

Pengakuan Van Den Berg tersebut bukan tanpa alasan, karena banyak bukti yang mengindikasikan bahwa dalam praktik keagamaan, hukum Islam dilaksanakan secara menyeluruh oleh masyarakat yang beragama Islam. Hal ini dibuktikan dengan adanya pelbagai aturan pada berbagai daerah terkait pemberlakuan hukum Islam, antara lain sebagai berikut: ${ }^{17}$

1) Adanya Compedium Freijher, yaitu buku ringkasan tentang hukum perkawinan dan kewarisan Islam. Buku ini merupakan pedoman para pihak untuk wilayah hukum daerah jajahan VOC sebagai tindak lanjut diberlakukannya Statuta Batavia

15 Lihat, Abdul Manan, Aneka Masalah Hukum Perdata Islam, ( Jakarta: Kencana, 2006), 292

16 Abdul Manan, Aneka Masalah Hukum Perdata Islam..292.

17 Oyo Sunaryo Mukhlas, Perkembangan Peradilan... 121 
1642, yang menyebutkan: "sengketa warisan antara pribumi yang beragama Islam harus diselesaikan dengan menggunakan hukum Islam";

2) Digunakannya kitab Muharrar dan Pepakem Cirebon untuk wilayah Kesultanan Cirebon;

3) Digunakannya kitab Sabīl alMuhtadīn (syarah kitab shirāth alMustaqim, karangan Syaikh Nuruddin ar-Raniri) di daerah Kesultanan Banjar;

4) Stbl. 1882 Nomor 152 tentang pembentukan Peradilan Agama,yang diberi nama Priesteraad untuk Jawa dan Madura. ${ }^{18}$

Berdasarkan bukti-bukti di atas, dapat disimpulkan bahwa hukum Islam sudah menjadi satu kesatuan yang tidak terpisahkan dalam kehidupan masyarakat muslim pada waktu itu. Orang Islam melaksanakan sayariat Islam atas dasar legitimasinya adalah perintah Allah, Swt., dan Rasul-Nya. Umat Islam mempertahankan agamanya salah satunya dengan cara mengaplikasikan syari'atnya tanpa reserve (teori tentang otoritas hukum). Dengan munculnya teori receptio in complexu, semakin mempertegas dan memperkuat penerapan hukum Islam bagi masyarakat muslim. ${ }^{19}$

\section{TEORI RECEPRIE: SEJARAH KEMUNCULAN}

Sebelum kedatangan Snouck Hurgronje Hurgonje ${ }^{20}$ ke Indonesia,

\footnotetext{
18 Oyo Sunaryo Mukhlas, Perkembangan Peradilan... 121

${ }^{19}$ A. Rahmat Rosyadi dan Rais Ahmad, Formalisasi Syariat Islam dalam Perspektif Tata Hukum Indonesia, (Bogor: Ghalia Indonesia, 2006), 77

${ }^{20}$ C.S. Hurgronje adalah anak seorang Pastur Gereja Gereformeerd (Calvinist), ia lahir pada tanggal 8 Februari 1857. Pada usia 18 tahun ia masuk Fakultas Theologi Leiden. Setelah lulus kandidat examen, kemudian ia pindah ke Fakultas Sastra jurusan Arab.
}

kebijaksanaan-kebijaksanaan kolonial Belanda terhadap Islam di Indonesia tidaklah memiliki arah yang jelas. Hal ini disebabkan miskinnya pengetahuan kolonial Belanda tentang Islam dan Indonesia, atau mungkin "buta" sama sekali. Pada masa itu kebijaksanaan kolonial Belanda terhadap Islam di Indonesia, secara tradisional dibentuk oleh kombinasi yang kontradiktif antara ketakutan dan pengharapan yang berlebihlebihan. ${ }^{21}$

Sehingga dengan kondisi demikian, pihak kolonial Belanda dalam menghadapi realitas yang terjadi pada umat Islam di Indonesia hanya mampu membiarkan terhadap hukum Islam untuk diamalkan dengan penuh ketaatan oleh umat Islam, tanpa mampu melakukan campur tangan karena dikhawatirkan adanya perlawanan dari umat Islam.

Oleh sebab itu, pihak pemerintah Kolonial Belanda sangat takut terhadap muslim fanatik yang mempunyai hubungan dengan dunia internasional, termasuk bahaya permintaan bantuan kepada negara Islam di luar negeri. Rezim Belanda di Indonesia sangat takut terhadap sesuatu yang berbau Pan Islamisme. Islam dibayangkannya sebagai sebuah agama yang diorganisir secara rapi, dalam banyak hal dianggap serupa dengan agama Katholik Roma yang memiliki susunan kebiaraan hirarchis yang bersekutu dengan Sultan Turki. Akibatnya, Islam di mata

Setelah berhasil meraih gelar Doktor dalam bidang Sastra Semit (1880) ia menjadi dosen di Leiden, dalam Institut yang mempersiapkan pegawaipegawai Belanda untuk Indonesia (Indologie). Jabatan tersebut dipegangnya sampai tahun 1887. Selama itu pula ia menyelidiki Fiqih (Hukum Islam), biografi Nabi Muhammad SAW dan sejarah Islam. Lihat, Effendi, dalam "Politik Kolonial Belanda, Jurnal TAPIs Vol.8 No.1 Januari-Juni 2012, 95

${ }^{21}$ A. Rahmat Rosyadi dan Rais Ahmad, Formalisasi Syariat Islam dalam Perspektif Tata Hukum Indonesia, 92 
penjajah Belanda nampak sebagai musuh yang menakutkan, maka tidak mengherankan apabila pemerintah kolonial Belanda pada waktu itu bertindak sangat membatasi ruang gerak umat Islam di Indonesia; terutama dalam hal pergi haji ke Makkah yang dianggapnya sebagai biang keladi yang menimbulkan agitasi dan pemberontakan di Indonesia. $^{22}$

Hukum Islam di Indonesia yang keberadaannya telah dijalankan dengan penuh kesadaran oleh umat Islam sebelum kolonial Belanda datang, membuat realitas tersebut diatas mendorong merela, pada saat pertama kali datang ke Nusantara pada abad ke $17 \mathrm{M}$, untuk mengetahui eksistensi hukum Islam. Bahkan setalah cukup lama diam, tanpa campur tangan sama sekali, Belanda mulai mengeluarkan kebijakan terhadap keberadaan hukum Islam. Melalui kantor dagang Belanda VOC (1602-1880). Pada Mei 1760 di keluarkan Resolutie der Indehe Regeering yang berisi ketentuan diberlakukannya sekumpulan aturan hukum perkawinan dan hukum kewarisan menurut hukum Islam untuk dipergunakan pada pengadilan VOC bagi orang Indonesia. Resolusi yang terkenal dengan nama Conpendium Freiyer ini dalam batas tertentu bisa dikatakan sebagai legislasi pertama hukum Islam di Indonesia. ${ }^{23}$

Pada mulanya, politik kolonial Belanda sebenarnya cukup menguntungkan posisi hukum Islam, setidaknya sampai akhir abad ke 19 M. Dengan dikeluarkanya staatsblad No 152 Tahun 1882 yang mengatur sekaligus mengakui adanya lembaga Peradilan Agama di Jawa dan Madura, hal ini merupakan indikasi kuat diterimanya hukum Islam oleh pemerintah kolonial. Dari sini muncul teori Receptio in

\footnotetext{
${ }^{22}$ A. Rahmat Rosyadi dan Rais Ahmad, Formalisasi Syariat Islam dalam Perspektif Tata Hukum Indonesia..92

${ }^{23}$ Idris Ramulyo, Azas Azas Hukum Islam, (Jakarta: Sinar Grafika, 1997), 12
}

Complexu yang dikembangkan oleh lodewijk Willem Chritian Van Den Berg (1845-1927), yang menurutnya bahwa orang Islam Indonesia telah melakukan receptie hukum Islam dalam keseluruhannya dan sebagai satu kesatuan. Hukum Islam telah di amalkan secara penuh oleh umat Islam ketika itu, dengan adanya teori ini maka hukum Islam berada diatas angin bagi keberlakuaannya, sejajar dengan sitem hukum yang lain. ${ }^{24}$

Namun demikian, seiring adanya perubahan orientasi politik yang cukup signifikan, Belanda mulai melakukan penyempitan bagi ruang gerak dan perkembangan hukum Islam. Fenomena ini bisa dianggap sebagai upaya untuk mengeleminasi perkembangan dari legislasi hukum Islam di Indonesia, yang tanpa disadari semakin mengokohkan eksistensi Belanda itu sendiri. Mereka menyadari bahwa jika hukum Islam dibiarkan terus berkembang dan di anut oleh masyarkat luas maka hal itu akan menghambat ekspansi dan juga sosialisasi dakwah mereka.

Setelah kehadiran Snouck Hurgronje Hurgronje, kebijaksanaan-kebijaksanan politik Belanda terhadap Islam di Indonesia mulai didasarkan pada landasan ilmiah yang mengutamakan fakta-fakta obyektif. Ia memang merupakan negarawan Belanda yang benar-benar besar dan ahli mengenai masalah penjajahan. Pengetahuannya yang mendalam tentang Islam di Indonesia, telah mendorong pemerintah kolonial Belanda pada tahun 1889 mengangkatnya menjadi penasehat pada sebuah kantor pemerintah yang menangani masalah-masalah Arab dan pribumi ${ }^{25}$.

Melalui ide yang di kemas dalam konsep Het Indiche Adatrect dengan tokoh intelektualnya Van Vollen Hoven (18741933 dan C.S Hurgronje (1857-1936), yang

\footnotetext{
${ }^{24}$ Mahsun Fuad, Hukum Islam..., 51-52

${ }^{25}$ Effendi, Politik Kolonial Belanda ..., 98
} 
kemudian dikenal dengan teori Receptie, pemerintah kemudian melakukan upaya penyempitan terhadap keberlakuan hukum Islam. Menurut teori ini, hukum yang berlaku bagi umat Islam adalah hukum adat mereka masing masing, hukum Islam dapat berlaku apabila telah direceptie oleh hukum adat, jadi hukum adatlah yang menentukan ada tidaknya hukum Islam. ${ }^{26}$ Hukum adat bagi teori receptie menjadi tolak ukur layak atau tidaknya hukum Islam diterima dan dijadikan hukum bagi umat Islam. Hal ini dilakukan sebagai upaya pihak kolonial terhadap umat Islam, agar semakin mengurangi pelaksanaan hukum Islam.

Bagi Snouck Hurgronje Hurgronje bahwa selama ini sikap politik Belanda terhadap umat Islam merugikan pemerintah Belanda sendiri, sehingga dengan pemberlakuan teori receptie umat Islam menjadi jauh terhadap hukum agamanya, sebab pada umumnya orang yang kuat memegang agama Islam (Hukum Islam) tidak mudah mempengaruhi orang peradaban Barat.

Dengan demikian, ada relevansi terhadap ketaatan seorang muslim terhadap ajaran agamanya dengan penolakan mereka terhadap pemerintahan Kolonial Belanda dan kebudayaannya. Oleh sebab demikian, Snouck Hurgronje berupaya menjauhkan umat Islam dari ajaran agamanya. Hal ini dilakukan sebagai upaya agar pemerintahan Belanda yang ada di Indonesia semakin kuat tanpa adanya perlawanan-perlawanan dari kalangan pribumi.

Sebagai penasehat pemerintah Kolonial Belanda, Snouck Hurgronje juga memberikan nasehat yang terkenal denan sebutan "Islam Policy". Ia merumuskan nasehatnya pada pemerintah Belanda dalam mengurus umat Islam di Indonesia dengan usaha menarik rakyat pribumi agar lebih mendekat kepada kebudayaan Eropa dan

\footnotetext{
${ }^{26}$ Mahsun Fuad, Hukum Islam..., 51-52
}

pemerintah Kolonial Belanda. Nasehat ini berintikan bahwa masalah yang menyangkut ibadah umat Islam harus diberikan kebebasan sepenuhnya, dan pada masalah sosial kemasyarakatan pemerintah Belanda harus menghormati terhadap adat istiadat dan kebiasaan rakyat yang berlaku, hal ini dilakukan guna mendekatkan rakyat terhadap kolonial Belanda. Akan tetapi dalam masalah ketatanegaraan, pemerintah kolonial Belanda tidak boleh memberikan kesempatan kepada umat Islam, dan harus mencegah hal-hal yang bisa membantu adanya gerakan Pan Islamisme. ${ }^{27}$

Namun begitu, Snouck Hurgronje tetap memperingatkan, agar Islam baik sebagai kekuatan politik maupun agama tidak boleh dipandang sebelah mata. Di sini ia menolak pandangan-pandangan yang keliru dari kalangan agamawan Belanda, terkait "kaum abangan". Menurutnya, walaupun ke-Islamannya tidak murni, tetap menganggap dan merasa bahwa dirinya benar-benar sebagai orang Islam yang taat menurut versi imannya. Oleh karena itu Snouck Hurgronje tidak membenarkan pandangan yang meremehkan bahwa mereka akan dengan mudah untuk diKristenkan. Bahkan cepat atau lambat keislaman mereka akan semakin kuat baik segi kualitas maupun kuantitasnya ${ }^{28}$. Dengan demikian, keberadaan Islam yang dianut oleh mayoritas masyarakat nusantara tidak boleh disepelekan. Karena walaupun sebuah agama, Islam dengan segala doktrinnya memiliki tempat tersendiri dikalangan semua pemeluknya, tidak terkecuali "kaum abangan". Terlebih dengan adanya doktrin jihad dalam Islam, membuat keberadaannya tidak boleh dipandang dengan segala mata.

\footnotetext{
27 Aqib Suminto, Politik Islam Kolonial Belanda (Jakarta: LP3ES, 1985), 12.

${ }^{28}$ Effendi, Politik Kolonial Belanda... 99
} 
Pandangan Snouck Hurgronje tersebut, menjadi dasar bagi kolonial Belanda membuat dasar hukum terhadap teori receptie ini, yaitu Undang-Undang Dasar Kolonial Belanda yang menjadi pengganti RR yang disebut Wet $O p$ De Staat Snrichting Van Nederlands Indie, yang disingkat Indische Staat Regeering (IS) yang diundangkan pada tahun 1929. Lebih lanjut disebutkan pada Pasal 134 Ayat (2), yang berbunyi "Dalam hal terjadi perkara perdata antara sesama orang Islam diselesaikan oleh hakim agama Islam apabila hukum adat mereka menghendakinya dan sejauh tidak ditentukan lain dengan suatu ordonansi”. Tetapi pada kenyataannya, kebijaksanaan pemerintah Belanda ini sebenarnya justru ingin meruntuhkan dan menghambat pelaksanaan hukum Islam, diantaranya dengan cara: ${ }^{29}$

1. Dalam hukum pidana, tidak memasukkan hudud dan qishash. Hukum pidana yang berlaku bersumber langsung Wetboek van Strafrecht dari Belanda yang berlaku sejak Januari 1919 (Stbl. 1915: 732);

2. Dalam hukum tata negara, ajaran Islam yang menyangkut hal tersebut dihilangkan. Pengajian al-Qur'an dan Sunnah yang memberikan pelajaran agama dalam politik kenegaraan atau ketatanegaraan dilarang;

3. Dalam hukum mu'amalah, dipersempit hanya menyangkut hukum perkawinan dan kewarisan. Hukum kewarisan Islam pun mulai diminimalisir dengan langkahlangkah sistematis.

Dengan diberlakukannya teori receptie itu, maka hukum Islam tidak dapat

\footnotetext{
${ }^{29}$ A. Rahmat Rosyadi dan Rais Ahmad, Formalisasi Syariat Islam... 78
}

bebas diberlakukan diseluruh pelosok nusantara. Dibasis-basis yang umat Islamnya minoritas, sudah barang tentu pemberlakuan hukum Islam mendapat ganjalan, karena adat setempat tidak akan mengakui hukum Islam sebagai adat. Kondisi tersebut pada ujungnya mempengaruhi pelegislasian hukum Islam pasca penjajahan kolonial Belanda, hal tersebut tentu berbalik pada masa munculnya kerajaan-kerajaan Islam di Indonesia yang menjadikan hukum Islam sebagai sumber hukum.

\section{PERKEMBANGAN HUKUM ISLAM PASCA TEORI RECEPTIE}

Dalam perjalanan sejarah tercatat jelas bahwa teori receptie diambil alih menjadi politik hukum kolonial Belanda yang secara sistematis dan konsepsional digunakan untuk mempersempit ruang gerak hukum Islam. Hasilnya adalah dikeluarkannya beberapa peraturan yang menggeser eksistensi dan esensi Pasal 75 dan 78 RR 1855, sehingga refleksi hukum Islam semakin memudar "dan akhirnya hilang". 30

Penentangan umat Islam terhadap pemberlakuan teori receptie terus dilakukan, tidak hanya selama penjajahan Belanda, akan tetapi terus berlanjut hingga Indonesia merdeka. Para ahli hukum mencermati betul implikasi dari pemberlakuan teori receptie tersebut, yakni menjadikan umat Islam Indonesia menjauhi hukum agamanya ${ }^{31}$.

Sehingga tanpa disadari pengaruh tersebut terus berkelanjutan yang pada ujungnya adalah mempengaruhi pemikiran pemberlakuan hukum di Indonesia dikalangan para ahli hukum.

\footnotetext{
${ }^{30}$ A. Basiq Djalil, Peradilan Agama di Indonesia, (Jakarta: Prenada Media Group, 2010), 42

${ }^{31}$ A. Rahmat Rosyadi dan Rais Ahmad, Formalisasi Syariat Islam... 81
} 
Makna tersembunyi di balik pemberlakuan teori ini adalah dihadapkannya pihak kolonial Belanda ketika itu dengan tiga konsep hukum yang masing-masingnya memiliki karakter tersendiri. Ketiga konsep dimaksud adalah hukum Islam, hukum Barat, dan hukum adat. Adanya ketiga konsep ini sudah dapat dipastikan bahwa Belanda akan menetapkan hukum yang lebih menguntungkan mereka, yakni hukum adat. Apabila hukum yang diberlakukan adalah hukum Belanda, maka akan menimbulkan kebencian dan perlawanan yang besar dikalangan umat Islam. Dengan demikian, pemilihan hukum adat oleh Belanda sebagai sistem hukum yang berlaku bagi kaum pribumi, khususnya umat Islam, bertujuan untuk mengeleminasi laju pelegislasian hukum Islam.

Karena bagi Belanda, pembiaran dan pelegitimasian hukum Islam bagi kalangan umat Islam di Indonesia dapat mengancam eksistensi kolonial Belanda di bumi Nusantara untuk mengeksploitasi kekayaan alam Indonesia. Karena selama ini pihak yang senantiasa menentang dan mengadakan perlawanan terhadap kolonial Belanda adalah umat Islam. Dengan begitu, pemberlakuan teori receptie bertujuan untuk menjauhkan umat Islam dari ajaran agamanya.

Atas dasar pandangan sejarah tentang ketiga sistem hukum tersebut yang berlaku di wilayah Nusantara maka setelah Indonesia merdeka dan menyatakan keyakinan bahwa Piagam Jakarta Tanggal 22 Juni 1945 menjiwai UUD 1945 merupakan satu rangkaian dengan Konstitusi tersebut, seperti yang tercantum dalam pasal 29 UUD 1945, yang selanjutnya merupakan dasar dan nilai-nilai bagi kehidupan keagamaan. Dengan demikian kedudukan hukum Islam dalam sistem hukum Indonesia memegang peranan yang sangat penting sehingga mendapat perhatian yang besar sebagai salah satu pokok bahasan dalam Konferensi Kementerian Kehakiman di Salatiga pada tahun 1950. Pada konferensi tersebut, Hazairin mengemukakan terkait masalah hubungan hukum Islam dengan hukum adat adalah bahwa dalam hal pemberlakuan hukum Islam tidak lagi disandarkan pada hukum adat, namun secara langsung berlaku atas dasar peraturan perundangundangan sebagaimana halnya memberlakukan hukum adat di Indonesia atas dasar perundang-undangan ${ }^{32}$.

Apa yang dilakukan oleh pihak Belanda dengan politik hukumnya melalui teori receptie, pada akhirnya meninggalkan pengaruh yang tidak mudah hilang pasca hengkangnya mereka dari Indonesia. Pengaruh teori receptie ini masih melekat pada masa awal kemerdekaan atau pada masa pemerintahan orde lama, dan bahkan sampai pada masa pemerintahan Orde Baru (1967-1998).

\section{Hukum Islam Masa Penjajahan Jepang}

Pada tahun 1942 Belanda meninggalkan bumi Indonesia sebagai akibat dari pecahnya perang pasifik. Kedatangan Jepang mula-mula disambut dengan senang hati dan penuh harapan oleh bangsa Indonesia, termasuk sebagian besar umat Islam.

Sebagai aggressor, baik Belanda maupun Jepang sebenarnya memiliki tujuan yang sama, yaitu ingin mengeksploitasi umat Islam sebagai penduduk mayoritas untuk mempercepat maksud mereka menguasai bumi nusantara ini. Akan tetapi, keduanya memiliki kebijakan yang berbeda,

32 Sirojul Munir, dalam Pengaruh Hukum Islam Terhadap Politik Hukum Indonesia, Istinbath: Jurnal Hukum Islam, 92. 
terutama dalam menghadapi hukum Islam dan para pelaku hukum Islam. ${ }^{33}$

Berbeda dengan kebijakan Belanda yang tidak memberi peluang terhadap umat Islam untuk bergerak dalam bidang politik, hukum, dan peradilan dengan berbagai peraturan yang telah dibuat. Kebijakan Jepang yang ditempuh adalah dengan merangkul pemimpin Islam untuk diajak bekerjasama. Karena itu, para pemimpin Islam banyak yang dilibatkan dalam penyelenggaraan pemerintah dan latihanlatihan militer. Hal itu sangat menguntungkan umat Islam dan bangsa Indonesia. Kebijakan Jepang yang lain adalah mengakui kembali organisasiorganisasi Islam yang sebelumnya dibekukan.

Dengan kebijakan politik Jepang yang menganggap dirinya sebagai "saudara tua" bagi Indonesia, maka mereka cenderung merangkul umat Islam untuk ikut berperan aktif dalam laju pemerintahan. Kebijakan tersebut dimanfaatkan oleh umat Islam untuk menghidupkan kembali organisasiorganisasi Islam yang selama ini dilarang oleh pihak Belanda, untuk menyebarkan hukum Islam kepada para anggotanya. Yang pada akhirnya terbentuklah pengajian-pengajian baik di langgar, masjid, maupun lapangan yang biasanya mendatangkan para kiai terkenal.

Tindak lanjut dari politiknya tersebut, Jepang kemudian membentuk BPUPKI (Badan Penyelidik Usaha Kemerdekaan Indonesia) untung menyusun UUD Negara, para pemimpin Islam menuntut agar ditegaskan bahwa Negara yang akan dibentuk harus mendukung kedudukan (hukum) Islam. Namun tuntutan ini ditolak,

\footnotetext{
${ }^{33}$ Warkum Sumitro, Perkembangan Hukum Islam, (Malang: Bayumedia Publishing, 2005), 82
}

akhirnya disetujui rumusan kompromi yang dituangkan dalam Piagam Jakarta. ${ }^{34}$

Dalam piagam Jakarta, wakil dari golongan Islam yang hanya terdiri dari $20 \%$ dari keseluruhan anggota BPUPKI setidaknya berhasil memberi tambahan rumusan sila pertama yang berbunyi "Ketuhanan dengan kewajiban menjalankan syariat Islam bagi pemeluk-pemeluknya". Namun dalam pembentukan PPKI (Panitia Pesiapan Kemerdekaan Indonesia) rumusan sila tersebut gagal dipertahankan yang akhirnya berganti menjadi "Ketuhanan Yang Maha Esa". Namun, golongan Islam menganggap kata tersebut sebagai nama lain dari Tauhid menurut Islam.

\section{Perkembangan Hukum Islam Pasca Kemerdekaan}

Berlakunya hukum Islam di Indonesia pasca kemerdekaan telah mengalami pasang surut seiring dengan politik hukum yang diterapkan oleh kekuasaan negara. Bahkan dibalik semua itu, berakar pada kekuatan sosial budaya yang berinteraksi dalam proses pengambilan keputusan politik. Namun demikian, hukum Islam telah mengalami perkembangan secara berkesinambungan. Baik melalui jalur infrastruktur politik maupun suprastruktur politik dengan dukungan kekuatan sosial budaya tersebut.

Menurut M. Atho Mudzhar, bahwa proses transformasi hukum Islam di Indonesia dipengaruhi oleh perbedaan cara pandang dalam bidang pemikiran hukum Islam, yang menurutnya dibagi menjadi empat jenis, yakni: kitab-kitab fiqh, keputusan-keputusan Pengadilan Agama, peraturan Perundang-undangan di negeri muslim, dan fatwa-fatwa ulama. ${ }^{35}$

\footnotetext{
34 Warkum Sumitro, Perkembangan Hukum Islam....82

35 M. Atho Mudzhar, Pengaruh Faktor Sosial Budaya terhadap Produk Pemikiran Hukum Islam,
} 
Ismail Sunny, mengilustrasikan politik hukum sebagai suatu proses penerimaan hukum Islam digambarkan kedudukannya menjadi dua periode yakni pertama, periode persuasive source di mana setiap orang Islam diyakini mau menerima keberlakuan hukum Islam itu; dan, kedua, periode authority source di mana setiap orang Islam menyakini bahwa hukum Islam memiliki kekuatan yang harus dilaksanakan. Dengan kata lain, hukum Islam dapat berlaku secara yuridis formal apabila dikodifikasikan dalam perundangundangan nasional. ${ }^{36}$

Dengan demikian, perkembangan hukum Islam lebih lanjut lagi pelegitimasian hukum Islam sebagai sebuah hukum yang mengikat dan memiliki kekuatan yang harus dilaksanakan bergantung dengan politik hukum yang dipegang oleh pemegang kekuasaan, yakni pemerintah. Berlaku atau tidaknya hukum Islam bergantung penuh padanya. Oleh sebab itu, keberadaan hukum Islam pasca kemerdekaan mengalami pasang surut, dan hal tersebut terjadi karena kebijakan yang dilakukan oleh masing-masing pemegang pemerintahan berbeda-beda, baik sejak orde lama sampai masa reformasi.

\section{Perkembangan Islam pada Masa Orde Lama}

Salah satu makna kemerdekaan bagi Bangsa Indonesia adalah terbebas dari pengaruh hukum Belanda. Menurut Hazairin, setelah Indonesia merdeka, walaupun aturan peralihan menyatakan bahwa hukum yang lama masih berlaku selama jiwanya tidak bertentangan dengan UUD 1945, seluruh peraturan pemerintahan

dalam Jurnal Mimbar Hukum No. 4 tahun II, (Jakarta: al-Hiakmah dan Ditbinbapera Islam 1991), 21-30

${ }^{36}$ Isma'il Sunny, Tradisi dan Inovasi Keislamart di IndonesIa dalam Bidang Hukum Islam, (Bandung: Ulul Albab Press, 1997), 40-43.
Belanda yang berdasarkan teori receptie tidak berlaku lagi karena jiwanya bertentangan dengan UUD 1945. Teori receptie harus keluar (exit) karena bertentangan dengan Al-Qur'an dan Sunnah Rasulullah, $\mathrm{Saw}^{37}$.

Perjuangan mengangkat hukum Islam juga dilakukan oleh para tokoh-tokoh Islam pada saat menjelang kemerdekaan. Hasilnya adalah disetujuinya rumusan kompromi yang dituangkan dalam Piagam Jakarta (Jakarta Charter) dengan tambahan rumusan sila pertama berbunyi ketuhanan dengan kewajiban menjalankan syari'at Islam bagi pemeluk-pemeluknya. Namun dalam persidangan-persidangan PPKI (Panitia Persiapan Kemerdekaan Indonesia) selanjutnya perjuangan tersebut mengalami kemunduran. Keinginan-keinginan golongan Islam yang telah diajukan sebelumnya semuanya ditolak, bahkan setelah proklamasi kemerdekaan, tujuh kata dalam Piagam Jakarta yang menjadi simbol kemenangan Islam dihapuskan, kata Allah dalam Mukaddimah diganti dengan Tuhan dan kata Mukaddimah diubah menjadi pembukaan $^{38}$.

Pada masa orde lama, perkembangan hukum Islam tidak mengalami perkembangan yang berarti, bahkan dapat dikatakan masa itu hukum Islam berada pada masa yang suram. Bukti pendegradasian nilai-nilai hukum Islam itu tampak pada Garis-Garis Besar Pola Pembangunan Nasional Semesta Berencana Tahapan Pertama, 1961-1969 bab II pasal 2 tentang bidang

\footnotetext{
37 Abdul Ghofur Anshori dan Yulkarnain Harahab, Hukum Islam Dinamika dan Perkembanganya di Indonesia, (Yogyakarta: Kreasi Total Media, 2008), 110

38 Warkum Sumitro, Perkembangan Hukum Islam.. 88-89
} 
mental/agama/kerohanian/penelitian yang menyatakan sebagai berikut: ${ }^{39}$

“ Melaksanakan manifesto politik dilapangan pembinaan mental/ agama/ kerohanian dan kebudayaan dengan menjamin syarat-syarat spiritual dan material, agar setiap warga dapat mengembangkan kepribadiannya dan kebudayaan asing".

Persyaratan tersebut membawa dampak yang luas terhadap pelaksanaan hukum Islam di Indonesia, karena pelaksanaan hukum agama (hukum Islam) selalu dikendalikan oleh manifesto politik. Oleh sebab itu, hukum Islam tidak mampu berkembang, karena pelegitimasian hukum Islam untuk dilaksanakan secara penuh bergantung dengan pandangan politik hukum yang dipegang oleh rezim orde lama pada waktu itu.

Upaya mendegradasikan nilai-nilai hukum Islam juga dilakukan oleh Soekarno dan kawan-kawan. melalui kebijakannya terhadap organisasi-organisasi Islam yang dinilainya memiliki peran besar dalam penegakan hukum Islam di Indonesia. Pemerintah melakukan pemangkasan partai politik dari 24 menjadi 10 partai saja. Partai yang dianggap membahayakan kekuasaan pemerintah (Soekarno) disingkirkan melaui berbagai putusan. Termasuk Masyumi yang amat berperan dalam penegakan hukum Islam di Indonesia dengan alasan Masyumi terlibat pemberontakan PRRI/Permesta. Tuduhan itu tidak sepenuhnya benar karena berdasarkan dokumen politik tidak ada indikasi keterlibatan Masyumi dalam PRRI. Yang terlibat adalah tokoh-tokoh secara pribadi, antara lain Moh. Natsir, Syafrudin Prawiranegara, dan Burhanudin Harahap. ${ }^{40}$

\footnotetext{
${ }^{39}$ Warkum Sumitro, Perkembangan Hukum Islam, , 108

40 Abdul Aziz Thabba, Islam dan Negara Dalam... 179
}

$\begin{array}{llrr}\text { Tindakan } & \text { nyata } & \text { yang } & \text { dilakukan } \\ \text { pemerintah } & \text { orde } & \text { lama } & \text { untuk }\end{array}$ mendegradasikan nilai-nilai dan kedudukan hukum Islam di Indonesia yakni dengan lahirnya ideologi "Nasakom" yang menyatukan paham "nasionalis, agama, dan komunis". Tindakan tersebut sangat tidak masuk akal karena Islam sebagai agama tauhid tidak mungkin bisa disatukan dengan komunis. Karena itu tindakan tersebut mendapat reaksi yang keras dari pemimpinpemimpin Islam waktu itu sehingga tidak bisa dikembangkan dan dalam waktu dekat ideologi ini terkubur dengan sendirinya. ${ }^{41}$

\section{Hukum Islam Pada Masa Orde Baru}

Persentuhan Islam dan politik pada masa Orde Baru sesungguhnya telah diawali sejak Orde Baru menerapkan kebijakan modernisasi, di mana stigma perkembangan pola pikir dan cara pandang bangsa Indonesia serta proses transformasi kultural dan perubahan sosial lebih banyak mengadopsi apa yang pernah terjadi di negara-negara Barat. Kiblat pembangunan di Indonesia yang sebelumnya mengarah ke Eropa Timur berbalik arah ke Eropa Barat dan Amerika. Banyak didapatkan kalangan cendekiawan dan kalangan intelektual mulai akrab dengan pemikiran-pemikiran Barat. $^{42}$

Sikap pro-kontra di kalangan mayoritas umat Islam dalam menanggapi modernisasi melahirkan tiga pola berikut: Pertama, pola apologi, yakni suatu bentuk sikap penolakan kalangan Islam terhadap segala nilai-nilai yang berakar pada wacana modernisasi. Bahkan pola pertama ini berasumsi bahwa modernisasi identik dengan westernisasi dan sekularisasi; Kedua, pola adaptif, yakni suatu bentuk sikap menerima sebagian nilai-nilai

\footnotetext{
${ }^{41}$ Warkum Sumitro, Perkembangan Hukum Islam.. 111

${ }^{42}$ R. Saija dan Iqbal Taufik, Dinamika Hukum Islam Indonesia, (Yogyakarta: Deepublish, 2016), 90-91
} 
modernisasi yang tidak bertentangan dengan ajaran Islam; Ketiga, pola kreatif, yakni suatu bentuk sikap dialogis yang lebih mengutamakan pendekatan intelektual dalam menanggapi modernisasi. Dari ketiga pola tersebut, tampaknya pola ketiga menjadi lebih dominan karena pendekatan intelektual yang dikembangkan oleh kalangan modernis dipandang lebih representatif untuk membangun tatanan Islam modern di Indonesia. Hal ini terjadi sebagai antitesa dari kalangan Islam konservatif yang lebih mengarah kepada upaya ideologisasi dan depolitisasi Islam secara formal yang mengakibatkan lahirnnya ketegangan dengan rezim Orde Baru. $^{43}$

Ketegangan tersebut pada ujungnya menempatkan Islam dalam posisi marjinal di pentas politik nasional pada gilirannya telah melahirkan berbagai ketegangan antara Islam dan negara. Sejarah telah mencatat hahwa dinamika hubungan Islam dan negara pada masa Orde Baru mengalami pergeseran yang bersifat antagonistik, resiprokal kritis sampai akomodatif. Hubungan antagonistik (19661981) mencerminkan pola hubungan yang hegemonik antara Islam dengan pemerintah Orde Baru. Keadaan negara yang kuat memainkan pengaruh ideologi politik sampai ke tingkat masyarakat bawah telah berlawanan dengan sikap reaktif kalangan Islam sehingga melahirkan konflik ideologi dan sekaligus menempatkan Islam sebagai oposisi. $^{44}$

Namun demikian, khusus dalam sudut pandang perkembangan hukum Islam di Indonesia kesempatan umat Islam untuk mendapatkan hak-haknya pada pola

\footnotetext{
${ }^{43}$ R. Saija dan Iqbal Taufik, Dinamika Hukum Islam Indonesia,... 90-

${ }^{44}$ M. Syafi'i Anwar, Pemikiran dan Aksi Islam Indonesia: Sebuah Kajian Politik tentang Cendekiawan Muslim Orde Baru, (Jakarta: Paramadina, 1995), 9
}

hubungan antagonistik lebih tampak. Posisi umat Islam yang begitu lemah, seperti ketika merumuskan UU Perkawinan No.1 tahun 1974, aliran kepercayaan dalam Pedoman Penghayatan dan Pengamalan Pancasila (P-4), isu ekstrim kanan, isu suku, agama dan ras (SARA), isu kristenisasi dan kebijakan ekonomi kapitalistik. Protes umat Islam atas UU Perkawinan No.1/1974 yang disusul dengan PP No.9/1975, dianggap sebagai usaha Orde Baru untuk menggeser Hukum Islam dari akar tatanan sosial masyarakat Islam di Indonesia. ${ }^{45}$

Kelahiran Undang-Undang Nomor 1 Tahun 1974 tentang Perkawinan menurut pendapat Hazairin dan Mahadi merupakan ajal bagi kematian teori receptie. Karena Pasal 2 ayat (1) Undang-Undang Nomor 1 Tahun 1974 dengan tegas menyatakan bahwa "perkawinan adalah sah apabila dilakukan menurut ketentuan hukum masing-masing agama dan kepercayaannya itu. Dalam hal ini menurut Daud Ali, bahwa sejak lahirnya undang-undang perkawinan nasional itu, maka: ${ }^{46}$

1) Hukum Islam menjadi sumber hukum yang langsung tanpa harus melalui hukum adat dalam menilai apakah perkawinan sah atau tidak;

2) Hukum Islam sama kedudukannya dengan hukum adat dan hukum Barat;

3) Negara Republik Indonesia dapat mengatur suatu masalah sesuai dengan hukum Islam sepanjang pengaturan itu untuk memenuhi kebutuhan hukum umat Islam.

Tetapi terlepas dari semua itu pada masa Orde Baru hukum Islam mengalami perkembangan yang cukup berarti

\footnotetext{
45 Hasanudin M. Saleh, HMI dan Rekayasa Asas Tunggal Pancasila, (Yogyakarta: Pustaka Pelajar, 1996), 88-90.

${ }^{46}$ Abdul Ghofur Anshori dan Yulkarnain Harahab, Hukum Islam Dinamika... 112
} 
diantaranya dengan dibentuknya hukum perkawinan (UU No. 1 tahun 1974), wakaf (UU No. 5 tahun 1960 dan PP No. 28 tahun 1997), dan pembentukan undang-undang peradilan agama (UU No. 7 tahun 1989).

\section{Perkembangan Hukum Islam pada Masa Reformasi}

Rezim Orde Baru yang berkuasa selama 32 tahun akhirnya runtuh, di tandai dengan mundurnya Soeharto dari kursi kepresidenan tanggal 21 Mei 1998. Hukum Islam pada era reformasi sebagai kelanjutan dari era sebelumnya dapat berkembang dengan pesat melalui jalur kultural. Hal itu sebagai konsekuensi logis dari kemajuan kaum muslimin (cultural) dibidang ekonomi dan pendidikan ${ }^{47}$.

Pada awal reformasi, kebijakan arah dan tujuan bangsa Indonesia diatur dalam GBHN tahun 1999. Dengan berlakunya GBHN tahun 1999 ini, hukum Islam mempunyai kedudukan lebih besar dan tegas lagi untuk berperan sebagai bahan baku hukum nasional ${ }^{48}$. Perkembangan hukum nasional pasca reformasi mencakup tiga elemen sumber hukum yang mempunyai kedudukan yang sama dan seimbang yaitu hukum adat, Barat dan Islam. Ketiganya berkompetisi bebas dan demokratis, bukan pemaksaan. ${ }^{49}$

Sejak bergulirnya era reformasi, cukup banyak peraturan perundangundangan yang mengakomodir nilai-nilai hukum Islam. Kondisi Islam pada masa era reformasi juga menunjukkan tanda-tanda positif seperti yang disampaikan Howard M. Federspiel yaitu:

47 Sudirman Tebba, Islam Pasca Orde Baru, (Yogyakarta: Tiara Wacana, 2001), XVII.

48 A. Qodri Azizy, Eklektisisme Hukum Nasional: Kompetisi Antara Hukum Islam dan Hukum Umum, (Yogyakarta: Gama Media Offset, 2004), 169

${ }^{49}$ A. Qodri Azizy, Eklektisisme Hukum Nasional: Kompetisi Antara Hukum Islam dan Hukum Umum.., 172
"Islam in Indonesia is now finding a new place in society and politics following the demise of New Order. Overall, the position of Islam and the range of its activities is benign. It provides values of considerable worth to its followers and to the Indonesian Republic. Some of the changes it has undergone since 1997 are positive especially the participation of Muslims in the political system, where they are now an important part of the leadership and Muslim parties are represented. ${ }^{50}$

"Islam di Indonesia sekarang ini menemukan tempat dihati masyarakat dan dunia politik mengikuti kegagalan yang diperlihatkan oleh perjanjian baru. Seluruhnya, posisi dalam Islam dan juga perluasan aktivitasnya berjalan dengan sangat baik. Islam memberikan nilai yang dianggap sangat tinggi bagi pemeluknya dan juga bagi Republik Indonesia. Beberapa perubahan yang terjadi sejak 1997 merupakan hal positif terutama berkaitan dengan pertisipasi kaum muslimin pada sistem politik yang ada di mana mereka sekarang ini merupakan bagian penting dari kepemimpinan dan perwakilan dari kelompok atau partai Islam".

Peraturan yang memuat nilai-nilai hukum Islam yang telah ditetapkan dalam bentuk undang-undang diantaranya yaitu:

1) Undang-Undang Nomor 38 Tahun 1999 tentang Pengelolaan Zakat;

2) Undang-Undang Nomor 17 Tahun 1999 tentang Penyelenggaraan Ibadah Haji;

3) Undang-Undang Nomor 10 tahun 1998 tentang Perbankan sebagai pengganti Undang-Undang

50 Howard M. Federspiel. Indonesia, Islam, and U.S. Policy. The Brown Journal of World Affairs, Spring 2002-volume ix, issue 1, www.watsoninstitute.org/bjwa/archive/9.1/indonesia / federspiel. pdf, 22 Januari 2018 
Nomor 7 Tahun 1992 tentang Perbankan;

4) Undang-Undang Nomor 41 Tahun 2004 Tentang Wakaf;

5) Undang-Undang Nomor 3 Tahun 2006 tentang Perubahan atas Undang-Undang Nomor 7 Tahun 1989 tentang Peradilan Agama;

6) Undang-Undang Nomor 18 Tahun 2001 tentang otonomi khusus bagi Provinsi Daerah Istimewa Aceh yang mana pemerintah memberikan kewenangan yang lebih luas untuk menyelenggarakan pemerintahan dan mengelola sumber daya alam dan sumber daya manusia, termasuk di dalamnya penegakan syariat Islam.

7) Undang-Undang Nomor 13 Tahun $2008 \quad$ Tentang Penyelenggaraan Ibadah Haji sebagai pengganti UndangUndang Nomor 17 Tahun 1999;

8) Undang-Undang Nomor 21 Tahun 2008 tentang Hukum Perbankkan Syaria;

9) Undang-Undang Nomor 19 Tahun 2008 tentang Surat Berharga Syariah Negara.

\section{DAFTAR PUSTAKA}

\section{Buku:}

Abdullah, Taufik. Sejarah Dan Masyarakat : Lintasan Historis Islam di Indonesia. Jakarta: Yayasan Obor Indonesia. 1994.

Ali dan Bahtiar Effendy, Fachry. Merambah Jalan Baru Islam Rekonstruksi Pemikiran Islam Indonesia Masa Orde Baru. Bandung: Mizan. 1986.

Anshori dan Yulkarnain Harahab, Abdul Ghofur. Hukum Islam Dinamika dan
Perkembanganya di Indonesia. Yogyakarta: Kreasi Total Media. 2008.

Anwar, M. Syafi'i. Pemikiran dan Aksi Islam Indonesia: Sebuah Kajian Politik tentang Cendekiawan Muslim Orde Baru. Jakarta: Paramadina. 1995.

Arifin, Bustanul. Pelembagaan Hukum Islam diIndonesia: Akar Sejarah dan Prospeknya. Jakarta: Gema Insani Press. 1996.

Azizy, A. Qodri. Eklektisisme Hukum Nasional: Kompetisi Antara Hukum Islam dan Hukum Umum. Yogyakarta: Gama Media Offset. 2004.

Barakatullah dan Teguh Prasetyo, Abd. Halim. Hukum Islam Menjawab Tantangan Zaman Yang Terus Berkembang, cet. 1. Yogyakarta: Pustaka Pelajar. 2006.

Bisri, Cik Hasan. Peradilan Agama di Indonesia. Jakarta: Raja Grafindo Persada. 2000.

M. Saleh, Hasanudin. HMI dan Rekayasa Asas Tunggal Pancasila. Yogyakarta: Pustaka Pelajar. 1996.

Mahsun Fuad, Hukum Islam Indonesia, (Yogjakarta: LKIS, 2005)

Mukhlas, Oyo Sunaryo. Perkembangan Peradilan Islam. Bogor: Ghalia Indonesia. 2011.

Noer, Deliar. Gerakan Modern Islam di Indonesia 1900-1942. Jakarta: LP3ES. 1985.

Ramulyo, Idris. Azas Azas Hukum Islam. Jakarta: Sinar Grafika. 1997.

Rosyadi dan Rais Ahmad, A. Rahmat. Formalisasi Syariat Islam dalam Perspektif Tata Hukum Indonesia. Bogor: Ghalia Indonesia. 2006.

Saija dan Iqbal Taufik, R. Dinamika Hukum Islam Indonesia. Yogyakarta: Deepublish. 2016. 
Suminto, Aqib. Politik Islam Kolonial Belanda. Jakarta: LP3ES. 1985.

Sumitro, Warkum. Perkembangan Hukum Islam. Malang: Bayumedia Publishing. 2005.

Sunny, Isma'il. Tradisi dan Inovasi Keislamart di IndonesIa dalam Bidang Hukum Islam. Bandung: Ulul Albab Press. 1997.

Surya Negara, Ahmad Mansur. Menemukan Sejarah: Wacana Pergerakan Islam di Indonesia. Bandung: Mizan. 2002

Syaltut, Mahmud. Al-Islām 'Aqīdatu wa Syarī'atu. Beirut: Dār Syuruq. 1983

Tebba, Sudirman. Islam Pasca Orde Baru. Yogyakarta: Tiara Wacana. 2001.

Thabba, Abdul Aziz. Islam dan Negara Dalam Politik Orde Baru. Jakarta : Gema Insani Press. 1998.

Wahid dan Rumadi, Marzuki. Fiqh Madzhab Negara. Yogyakarta: LkiS. 2001.

\section{Jurnal:}

Effendi. Politik Kolonial Belanda. Jurnal TAPIs Vol.8 No.1 Januari-Juni 2012.

Federspiel, Howard M. Indonesia, Islam, and U.S. Policy. The Brown Journal of World Affairs, Spring 2002volume ix, issue 1 , www.watsoninstitute.org/bjwa/archiv e/9.1/indonesia/ federspiel. pdf

Ghofur, Abdul. Tela'ah Kritis Masuk dan Berkembangnya Islam di Nusantara, http://ejournal.uin-

suska.ac.id/index.php/ushuludin/articl e/view/689.

Mudzhar, M. Atho. Pengaruh Faktor Sosial Budaya terhadap Produk Pemikiran Hukum Islam. Jurnal Mimbar Hukum No. 4 tahun II. 1991

Munir, Sirojul. Pengaruh Hukum Islam Terhadap Politik Hukum Indonesia. Istinbath: Jurnal Hukum Islam.

Teguh Iman Santosa, Nyong Eka. Membaca Masuknya Islam di Indonesia", eprints.umsida.ac.id/184/.../teori\%20 masuknya\%20Islam\%20ke\%20nusant ara-2005. 